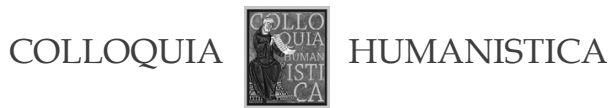

\author{
Piotr P. Płucienniczak \\ Faculty of Management of Visual Culture, \\ Academy of Fine Arts in Warsaw \\ Warsaw \\ https://orcid.org/0000-0003-4814-695X \\ piotr.plucienniczak@asp.waw.pl
}

\title{
Examining the Boundaries of Contemporary Art: An Exploratory Study of Institutional Critique in Poland 1990-2015
}

\begin{abstract}
The article explores the practices of institutional critique in Polish contemporary art. A quantitative survey of cases of institutional critique reveals major problems faced by artists and their perceptions of the autonomy of the visual arts.

Keywords: contemporary art, institutional critique, sociology of art, visual arts.

\section{Exploring Institutional Critique}

$\bar{A}$ s one leading Polish art critic and curator wrote: "Institutional Acritique is doing well. Institutional critique does not exist" (Ujma, 2013). What does "institutional critique" even mean? Is there such a thing in Polish contemporary art? What does it look like? How do artists, curators and other actors criticize art while practicing it? How do participants in the art field study their own institutions and art's borders with the broader social environment? This field is open to exploration.

By following what is criticized, one can follow artists' own perception of contemporary art: their grievances, discontents and interests. There are

This is an Open Access article distributed under the terms of the Creative Commons Attribution 3.0 PL License (creativecommons.org/licenses/by/3.0/pl/), which permits redistribution, commercial and non-commercial, provided that the article is properly cited. (c) The Author(s), 2019.

Publisher: Institute of Slavic Studies, Polish Academy of Sciences

Editor-in-chief: Jolanta Sujecka

Conception and academic editing of this issue: Katarzyna Roman-Rawska, Tomasz Rawski
\end{abstract}


several reports on the condition of artists and other art workers in Poland: They tend to lack social security and face problems trying to strike a balance between their professional and artistic careers (Kozłowski, Sowa, \& Szreder, 2013; Krajewski \& Schmidt, 2017), there are problems with gender inequality (Gromada, Budacz, Kawalerowicz, \& Walewska, 2015), contemporary art institutions struggle with insufficient funding (Głowacki et al., 2009), there is also a problem with the public image of contemporary art as such (Krajewski \& Schmidt, 2017). How do these problems translate into the language of art? Do they translate at all? Institutional critique is a practice of examining the boundaries of contemporary art: raising questions of its relations to the external world and the rules of the game within it.

Attempts have been made to understand the phenomenon of institutional critique (Raunig \& Ray, 2009; Sikora, 2015), but they are written from the perspective of art historians or art critics rather than social scientists. The difference is crucial: While the former study artworks as artworks, the latter are interested in artworks as a product of collective actions, influenced by institutions and social structures. In the perspective of social sciences, the artist is a worker, and his or her work tells us about the social conditions of its creation (Zolberg, 1990, p. 100). In the case of institutional critique, artwork also reflects upon those conditions.

The present study ${ }^{1}$ attempts to provide a quantitative insight into the phenomenon. Because of its pioneering character, it is a more of a sociological exploration into the field of contemporary art. Its aim is to trace phenomena to the social contexts that motivate the creativity of artists (and others) (Reiter, 2017, p. 140). In this sense, it is a "type 1" exploratory study, one that aims to provide empirical insight into a little-known topic rather than provide explicit answers and explanations (Swedberg, in press).

Institutional critique is an artistic practice that takes art institutions ("stable, valued, recurring patterns of behavior" [Huntington, 1968, p. 9]) as its object. In this study, I define institutional critique as statements and actions that reflect upon the conditions of the creation and distribution of art and the social relations involved in those conditions. That includes relations between different positions within art institutions and between art and other institutions, such as religion, politics or economy. In most cases, it takes an artistic form (an exhibition, artwork or performance), but is not confined to it:

We find it in the most diverse tactics of context politicization, self-masking, alienation, parody, the situation-specific refraction of themes, research, discursive

\footnotetext{
This article is a revised and expanded version of a paper entitled "Kondycja krytyki instytucjonalnej i krytyka instytucjonalna jako wskaźnik kondycji sztuki” published in Polish in Brożyński, 2016.
} 
and material context production, in self-institutionalization, in production that starts with social interaction, or even simply in a more or less developed renegade position. (Nowotny, 2009, p. 27)

Institutional critique (IC) does not negate the need for the existence of art institutions. It explores their possibilities, potential for change, possible new rules or new actors. As such, IC is the artistic equivalent of critical social theories that expose power structures and arbitrariness in social institutions. This means that it is a form of knowledge concerned with the social reality of art and beyond art (Smithson, 2009, p. 140; Young, 2001, pp. 104-105). It is also an element of a general struggle against injustice and is not confined to problems of art (Nowotny, 2009, p. 27). Stimson (2009, pp. 20-42) argues that institutional critique is a translation of demands of autonomy and resistance to bureaucracies of the state and the market into the language of contemporary art. Institutional critique is a reflexive mechanism. It is a method of artists' self-study and of examining the boundaries of contemporary art: what constitutes contemporary art, what shapes it from the outside, what influences it. That makes institutional critique a practice addressed to other participants in the art field rather than the general audience, because of its insider, esoteric nature (Bourdieu, 1996, p. 217). Its existence is an indicator of the autonomy of contemporary art, a realization of "the right and the duty to ignore the demands or requirements of temporal powers" (Bourdieu, 1996, p. 221) in the name of freedom to create and to judge art by its own standards ("rules of art"), not by those derived from politics or the market. In other words, to study institutional critique means to study the condition of contemporary art in the minds of its creators as they try to examine and modify the boundaries of their field.

The next part of the article describes the methodology and the data gathering process. The third part outlines the basic characteristics of the collected data: geographic and demographic features. The fourth part examines major topics of institutional critique, the relations between them, and their significance. The final part offers reflections on the social conditions that shape the phenomenon in question.

\section{Methodology of the Study}

The aim of the research was to create a quantitative database of episodes selected from sources on the basis of unified procedures. The study was carried out using a technique inspired by protest event analysis (Koopmans \& Rucht, 2002). The unit of analysis is an episode of institutional critique that can take various forms and be performed by various actors. However, the final form of the study has more in common with sociological exploration 
in the manner prescribed by Pierre Bourdieu (Bourdieu \& Wacquant, 1992). That is, it is based on creating subsets of objects sharing characteristics rather than quantitative, analytical studies of contentious activity.

The initial list of episodes was prepared by members of the research project Study of Practices of Polish Artists and Curators in the Light of Institutional Critique 1985-2014 (see: Brożyński, 2016). The list served as a starting point for collecting further data using snowball sampling (a typical methodology of exploratory studies [Swedberg, in press, p. 6]). Portfolios of featured artists, curators and institutions, exhibition staff, publications on contemporary art, periodicals and catalogs of exhibitions, as well as expert interviews with representatives of relevant institutions were all considered data sources. Artworks, exhibitions and other events (conferences, manifestos, founding acts of institutions) that in any way criticized, ridiculed or questioned existing art institutions, were considered to be episodes of IC and included in the database.

This is a fuzzy definition of a research unit and the resultant set is vulnerable to erroneous categorizations or omissions. What is more, the database is not homogeneous, as cases have different characters: For example, both exhibitions and the artworks presented in them are included. This approach, however, allows to capture actions and perspectives of both artists and curators as well as other actors.

The next step was coding of cases. Each one was described by a set of variables concerning basic characteristics (title, author, year, place, title of the exhibition, its curator, technique or form) and general issues raised (based on a description or interpretation of a given work). For example, Karol Radziszewski's exhibition Heal the World (2011) has been coded with "Social Problems in Art" and "Importance of Art": The artist referred to the problem of the limits of art using charitable gifts. The aim of this procedure was to avoid interpretations and analyses of relations between artworks. This is why critics' or curators' descriptions were considered fundamental for the procedure. This coding strategy is different from those already present in the literature. The editors of International Critique propose four a priori categories that they assign works to: "framing," "criticism," "institutionalization," "going out" (Alberro \& Stimson, 2009). Patrycja Sikora studies the topic using three categories: "self-treatment," "survival," "guerrilla" (Sikora, 2015). They both look for a unity of strategies within different implementations.

The list of variables/issues was modified several times and cases were re-coded to accommodate differences and retain the abstraction of codes. The final database consists of 184 cases: 123 artworks, 36 exhibitions, and 25 other episodes. 


\section{Temporal, Spatial and Demographic Outline}

Chart 1 shows that institutional critique did not stabilize within contemporary art in Poland until after 2001. The number of cases in the 1990s is negligible. This could be a consequence of the greater availability of contemporary episodes, but in fact, it is related to the prevalence of critical art in the first decade of the Third Republic. The mean of yearly cases in the period 1990-1999 is only 0.9, while the value increases to 11.4 in 2000-2009 and 10.6 in 2010-2015.

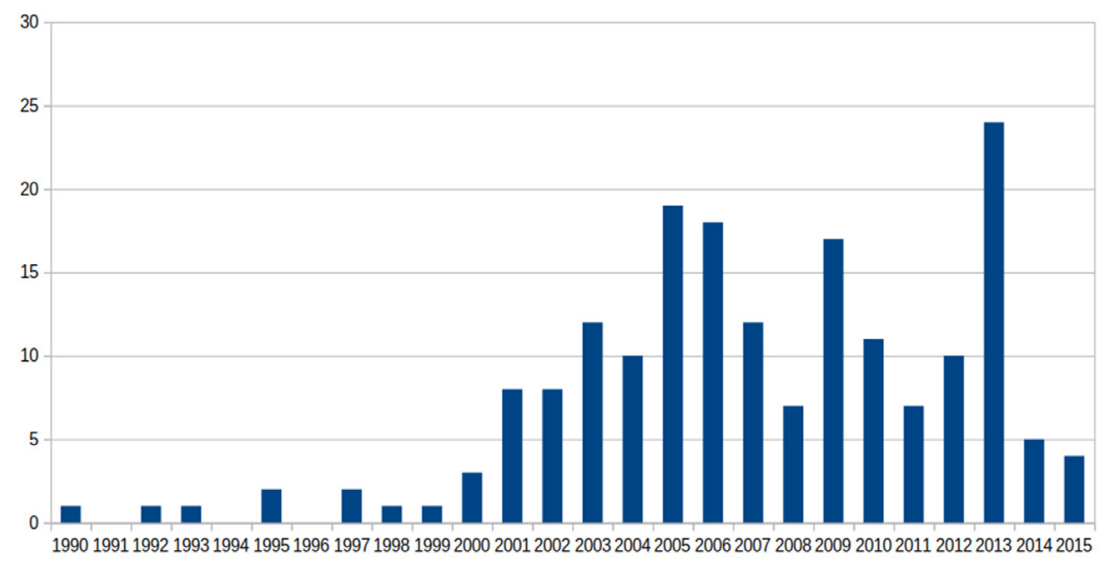

Chart 1 . Yearly count of coded cases of institutional critique. Source: own research.

In 2001, Zbigniew Libera organized an exhibition called Cold War in Kraków. In an article prepared for the occasion, he quoted right-wing press inciting against contemporary art. The event expressed awareness of antagonism and the urgent need to change communication between artists and the Polish audience. A year later, Jarosław Suchan curated the Four Rooms exhibition, a discussion on the role of art institutions, and organized the conference Polyphony of Voices on the critical contexts of curatorial work.

This was the beginning of rethinking of the politics of three major positions within the field of contemporary art: artists, curators, and managers of art institutions. Ronduda (2005) argues that it was a period when "The 'cold war' between art and society was replaced with artistic frictions and displacements between artists and institutions, tensions which were not formulated by artists before." With the new millennium, artists and curators turned from critical art towards institutional critique. This does not mean, however, that tension diminished. In 2002 Dorota Nieznalska's Passion sparked accusations of blasphemy. In the same year, Rafał Jakubowicz's Arbeitsdiziplin exhibition was blocked by representatives of Volkswagen. 
Nevertheless, as Sikora (2016) argues, 2001 should be considered the founding year of institutional critique in Poland.

The results of the study indicate a spatial centralization of IC practices in Poland. They took place most often at the Zachęta National Gallery of Art in Warsaw (15 distinct cases). Other sites include (in order of frequency): Bunkier Sztuki in Kraków, Muzeum Sztuki in Łódź, Warsaw’s Center for Contemporary Art Ujazdowski Castle and Raster gallery, and Kronika in Bytom. A special place on the list belongs to sites associated with the names of Grzegorz Klaman and Aneta Szyłak (Wyspa, Otwarte Atelier and Łaźnia in Gdańsk). All these institutions are the most important venues for contemporary art in Poland. Other sites hosted episodes of IC only sporadically, from one to three times in a quarter of a century. Besides Zachęta and Muzeum Sztuki, all of those on the list were founded relatively recently. Ujazdowski Castle was opened in 1985, Bunkier Sztuki in 1995, Raster and Kronika in 2001.

The list of institutions reveals the importance of directors. Muzeum Sztuki (Museum of Art) in Łódź and Bunkier Sztuki in Kraków both owe much to the self-critical Jarosław Suchan. The 25-year term of Wojciech Krukowski left a deep mark on the program of the Center for Contemporary Art Ujazdowski Castle. Grzegorz Klaman and Aneta Szyłak had been creating new, critical institutions since the 1980s. Kronika, under the leadership of Sebastian Cichocki and Stanisław Ruksza, quite consistently questioned its own role and position within the local political environment.

The database contains 97 different names of artists, curators, groups and others who have been involved in institutional critique in Poland. The most active include Paweł Althamer, Cezary Bodzianowski, Paulina Breguła, Oskar Dawicki and the Azorro Group, Roman Dziadkiewicz, Grzegorz Klaman, Paweł Kuśmirowski, Laura Pawela, Stanisław Ruksza, Aneta Szyłak and Julita Wójcik. These exact people are responsible for almost half of the collected episodes. This means that institutional critique in Poland is centralized not only institutionally, but also personally.

The ratio of men to women in the database is almost exactly $2: 1$. In spite of this, the status of women in art was rarely questioned. There are only a few episodes that referred to this inequality. Anna Okrasko's Female Painter Makes for a Painter's Wife and My Professor Paints in Stripes (both 2003) expose the reproduction of gender stereotypes in arts education. The scale of the problem was made visible in a report prepared by the Katarzyna Kozyra Foundation (Gromada et al., 2015). Julita Wójcik's Peeling Potatoes (2001) introduced "feminine" and "household" activities to the Zachęta National Gallery. Fading Traces, a documentary by Anka Leśniak (2011), told the stories of female artists who had abandoned art. Elżbieta Jabłońska’s Helping 
(2005) offered guided tours for single mothers as part of an exhibition curated by Tatar and Kuryłek. Although critical art of the 1980s and 1990s struggled to incorporate the feminine perspective into contemporary art, those experiences have not translated into institutional critique so far (Chadwick, 2012, pp. 378-422).

Considering age, the sample splits into two parts. In the first group are those who succeeded and their acts of critique are evenly distributed throughout their artistic career (e.g. Cezary Bodzianowski, Oskar Dawicki, Aneta Szyłak, Julita Wójcik). The second group contains young artists (e.g. Rahim Blak, Anna Okrasko, Laura Pawela and Maria Zuba), usually at the final stages of their education, who criticize authorities and the canon. However, their presence in the database is limited to a few statements and they soon disappear from the picture. Perhaps they have left the art world altogether. Both their creative practices and their decisions to leave art should be considered expressions of disagreement with the rules of contemporary art.

\section{Institutional Critique in Poland: Major Themes}

Every case in the database was assigned to one or more groups of related issues. Their order, based on the number of events categorized, is as follows: (1) financing of the arts, (2) history and infrastructure of an institution, (3) accessibility of art and the relationship with the audience, (4) power in art, and (5) alternative institutions. Only single cases referred to other topics, such as canonization, censorship, dark matter, gender inequality, international circulation, copyright and the notion of authorship. This is consistent with the recognition of what institutional critique deals with in theory (Raunig \& Ray, 2009) and does not indicate any uniqueness of the Polish case.

\subsection{Financing of the Arts}

Who should feed the heavenly bird of contemporary art? Financial grievances and discontent with the workings of the art market are the single most frequently voiced issue. The earliest episode encoded in this group is Appearance 29 by Przemysław Kwiek (1993). The movie presents an uncompromising (so far) artist who was forced to do commercial work (to paint flowers). In his later project, entitled The Avant-garde Is Painting Lilacs I The Avant-garde Is Selling Lilacs in Łomianki (2004), Kwiek showed that no picture was sold.

A series of works by Anna Okrasko and Laura Pawela reflects upon what the market is doing to art, or how an artist can find their place within the capitalist economy. The former identified the subject matter of a mandatecontract with a work of art, and "creative" work with "productive" work 
(Contract for a Work, How Do You Make Pictures, Picture Company OKRASKO, 2005). Pawela constructed a mass painting machine (Faster2, 2005) that also had to deal with an inadequate budget (Budget 500, 2005). Paintings truncated where the money ran out are reminiscent of Oskar Dawicki's Budget Story (2007). The film runs for a few minutes and all it shows is a renowned actor who screams "The money is about to run out!". Dawicki summarized his experiences of reconciling creative and professional work by hiding his own face in graphic designs he produced as an employee of an advertising agency (Help!, 2001). In I'm Sorry (2003) he apologized to the audience for failing to reach his own exhibition because his car broke down.

Institutions also experienced their own financial troubles. In Organizers Do Not Provide Any Support Hubert Czerepok (2000) sent an empty bosx to the Centre of Polish Sculpture in Orońsko. The package cost exactly what the organizers had offered him. Arek Pasożyt (Manifesto of Parasitism, 2010) moved into galleries, lived at their expense and even sublet their space. This activity was an alternative form of receiving royalties. The Azorro Group was less prone to collaboration. In The Proposal (2002) they laughed off an offer to participate in an unpaid exhibition.

During her residence abroad, Laura Pawela renovated the bathroom in her flat (2005). Anna Okrasko presented her contract with a gallery as a valuable art object (2005). Grzegorz Sztwiertnia prepared Bunkier Sztuki for sale (2012). Several activities pointed to the obscure way galleries build their collections. The Sędzia Główny Group offered to sell their works to a museum in a way reminiscent of corruption (2008). Cezary Bodzianowski tried to influence the decision of a gallery director in Looks 2003 (2003).

Art Attack by Iza Chamczyk (2010) was a singular testimony on the condition of private galleries in Poland. The artist closed the door during the opening and announced that until works worth 3,000 zlotys had been sold, no one would leave. As there were no buyers, security forces had to intervene and free the hostages. The exhibitions Freelancer, curated by Ewa Toniak (2013), and Workers of the Artworld, Unite! by Stanisław Ruksza (2013) explored the transformation of an artist into a worker.

\subsection{History and Infrastructure of an Institution}

This category explores the internal relations of an art institution, its mysteries and ambiguities. From a sociological perspective this is the least interesting group of the topic, as it is concerned with art as a creative endeavor rather that art as a social institution.

It is also the least homogeneous group, containing the playful provocations of Cezary Bodzianowski (O Sole Mio; Hey Bo, 1997), Magda 
Ziółkowska's exhibition on archiving (Working Title: Archive, 2009), some more and some less successful "attacks" on institutions (students of Mirosław Bałka, Pogo, 2010), studies on the relationship between gallery and society (Santiago Sierra, The History of the Foksal Gallery..., 2005), as well as experiments on gallery staff (Joanna Rajkowska, Exit, 2005; Łukasz Surowiec, Level, 2014).

Curators questioned exhibition spaces in works such as Jarosław Suchan's Four Rooms (2002), Aneta Szyłak's Palimpsest Museum (2002) and Kuryłek and Tatar's The Guide (2005). Artists who played the role of curators treated institutions nonchalantly: Grzegorz Sztwiertnia decommissioned Bunkier Sztuki (Liquidation, 2012), Karol Radziszewski ignored the canon (To Pee in a Bun, 2009) and Pola Dwurnik studied the building itself rather than artworks (Morphology of the Floor, 2015). This small but interesting collection of practices contains temporary suspensions of institutional division of labor. They are not only indicators of artists' thinking, but also critiques of arbitrary boundaries between positions within contemporary art.

History and collections are consistent points of reference for creative work. Questioning of the past is evident in episodes that took place at the Museum of Art in Łódź. During the exhibition The Museum as a Luminous Object of Desire (Henryk Lubiak, 2006) Elżbieta Jabłońska commemorated everyone who had hung their works in the museum, while Oskar Dawicki with Olga Stanisławska moved into the past of the institution. Zorka Wollny arranged Walk for a Collection of Art (2006) and Julita Wójcik organized the 3600 ms 2 Race (2008). The latter artist studied the fragility of art institutions in Feed the Heavenly Birds (2005).

\subsection{Accessibility of Art and the Audience}

Polish contemporary art had a bad reputation in the 1990s. However, with the start of the new millennium, the situation began to change. Artists, curators and directors actively searched for an audience and helped it understand art. This trend was part of broader shifts in the understanding of art institutions (new institutionalism) and artists' interests (relational aesthetics).

Zorka Wollny aestheticized the rituals of the audience in Walk for a Collection of Art (2006) at the Museum of Art in Łódź and other institutions. Karolina Breguła tried several times to improve communication between artists and their audience. In her graduation project, Sixty-Six Conversations About Contemporary Art (2007), she presented the amateur's point of view, while in I Don't Understand (2009) - a naive approach to contemporary art. Finally, in Translations of Art (2010) she helped to understand what exactly artists want to say through their works. The exhibitions There Is No 
Such Thing as Art (Tymek Borowski, 2015) and Art in Our Age (Żydek and Dominik, 2015) was also inviting and introductory in character.

One can treat Cezary Bodzianowski's happening 1003 Trinkets (2001) as a service to the accessibility of art. He helped random guests view famous impressionists' exhibitions at the National Museum in Kraków. During The Guide exhibition at the same museum, Elżbieta Jabłońska prepared a special program for single mothers who could leave their children safely and enjoy the art (2005). During Palimpsest Museum, Leszek Knaflewski prepared a set of wooden slippers for visiting the Museum of the City of Łódź (2002). This act highlighted the lack of facilities that would allow more people to participate in exhibitions.

On the other hand, the utopian nature of educational activities that do not take into account the complexity of social life was exposed by Santiago Sierra in The History of the Foksal Gallery Taught to an Unemployed Ukrainian (2002). Despite the invited Ukrainian's alleged willingness to learn, the educational process was humiliating for all those involved (Sikora, 2015, p. 70). Artists from the Azorro Group dealt with the problem jokingly when they showed contemporary family life saturated with contemporary art (2004).

The audience and naive artists not only observe but also fuel mainstream art. Robert Kuśmirowski's Palindrome (2015) and Magdalena Mazik and Elżbieta Sala's Private Interior (2014) explored the creativity of people with mental illness. Robert Althamer invited creators from outside the mainstream visual arts to his projects several times. Cezary Bodzianowski exhibited portraits painted by children in 2001. In the documentary Świecie (2010), Artur Żmijewski combined works of menial workers and artists to show the blurry boundaries between "physical" and "intellectual." Julita Wójcik emphasized the audience's responsibility for the sustained existence of art institutions in Feed the Heavenly Birds (2004).

The audience does not play an unambiguously positive role in Polish institutional critique. The negative reactions of the right-wing press were summarized in Cold War by Zbigniew Libera (2001). Goshka Macuga documented antisemitic attacks on the Zachęta National Art Gallery (2011). In 196 K.K. (2002), curator Grzegorz Klaman slapped Dorota Nieznalska as recommended by conservative commentators.

\subsection{Power in Art}

"Who rules in art?" is one of the fundamental questions of institutional critique. Unmasking the arbitrariness of power and striving for just relations is one of the key impulses of this category. 
The Cabinet by Rafal Jakubowicz (2006) studies the nonexistent merits of successive Polish ministers of culture. A counter to the state's attempts at reforming art institutions was prepared during an anti-congress of culture in Kraków (2009). The Manifesto of the Committee for Radical Changes in Culture called for social councils at institutions, social security for artists, and effective cultural education. The Occupation Festival (2014) was organized as a response to Poznań's municipal policy.

The activity of an anonymous group called The Krasnals involved a series of skirmishes with the artistic establishment. An open letter to the Polish prime minister and other figures of authority (2013) called for more democracy and criticized the decision to refuse to show their painting Battle of Grunwald. The Krasnals also parodied Polish artists so well that one of their paintings was considered to be Wilhelm Sasnal's original work and priced accordingly. At the same time, they conducted charity auctions, the proceeds from which were usually intended to support organizations helping children.

Traditional hierarchies of power were overturned when the roles of artist and curator were switched. Such situations occurred in Artur Żmijewski and Paweł Althamer's Elections.pl (2005), Robert Kuśmirowski's Collector's Massif (2009), Karol Radziszewski's To Pee in a Bun (2009) and Iza Tarasiewicz's Clinamen (2013). The curator's influence on an artist's significance was revealed in Portrait with a Curator (2002) by Azorro. In 196 K.K. (2002) it was the curator (Klaman) who punished the artist (Nieznalska) for violating a religious taboo.

There were also other attempts to undermine existing relations of power. Azorro awarded Quality Measures (2002) to art institutions. Robert Lisek initiated a DDoS attack on the website of the Awangarda gallery (2009). Roman Dziadkiewicz and Zorka Wollny staged The Kidnapping of the Curator (2004): They demanded greater accessibility of art and higher royalties. Probably the most recognized expression of tension between the artist and the curator was GingerAss by Piotr Uklański (2003). The question was: Should a curator expose his or her vulnerable side to the artist? Gender imbalance of power (Okrasko, Female Painters...) and mechanisms of canonization (Libera, Masters, 2003) were much less interesting to Polish artists.

\subsection{Alternative Institutions}

Artist-run spaces, art institutions organized by the artists themselves, are often progressive alternatives to traditional institutions and their division of labor. This does not mean that every foundation of a gallery is an act of institutional critique. Many such places function as "normal" galleries, more or less oriented toward commercial activities. From the perspective of the 
IC study, those institutions that propose their own definitions of what is art or are involved in politics are of particular interest. There are two types of such institutions: alternative spaces and mock-institutions.

The former are usually relatively small institutions that act in accordance with the rules of the game. They exhibit art and sometimes also sell it, educate etc. The most prominent include: Biała (Lublin), Entropia (Wrocław), F.A.I.T. (Kraków), Salony Foundation (Zielona Góra), Szara (Cieszyn), szu szu (Warsaw), Raster (Warsaw), Wschodnia (Łódź), Wyspa (Gdańsk) and Zona Sztuki Aktualnej (Szczecin). This list cannot be complete, considering the ephemerality that is characteristic of alternative institutions.

Mockinstitutions are informal institutions that distrust institutionalized authority, yet imitate actual functions of art institutions (Sholette, 2011, p. 13). An example of such action was the campaign of Wiktoria Cukt for the office of President of Poland, created by the CUKT collective in 2001. The virtual candidate was meant to prove that the traditional, nonvirtual political class is unnecessary. In 2005 Anna Okrasko founded the OKRASKO company that provided creative services and sold paintings. Museum of Deposited Art by Robert Kuśmirowski (2010) contains incinerated and cataloged works of other artists.

\section{Afterthoughts: What Does Institutional Critique Tell Us}

Practices of institutional critique are a stable element of contemporary art in Poland. Tensions will not decrease, as the research was carried out in the context of a political change that directly affected the material base of art institutions through cuts in funding for collections of contemporary art. This only exacerbates the problems already voiced by artists and others. We do not know yet whether it will stimulate a search for alternative sources of funding or inspire political actions.

The latter are very important, as a focus on IC should not obscure artists' contention that does not assume artistic forms. The Citizens Contemporary Art Forum (founded in 2009) and the milieu committee for art workers (incorporated by the Workers' Initiative trade union in 2013) intervene when the rights of artists or institution staff are violated. The Anti-Congress of Culture (2009), the Day without Art (2012) and the Beggars of Culture campaign (2015) were mobilizations in which people of art and culture at large protested against government policy. They can be treated as actions of a proper social movement: one that formulates demands, mobilizes resources, and establishes networks.

The study of institutional critique shows not only how artists criticize art, but also what happens to contemporary art as a social institution. The 
research was exploratory in character, so there are no hard conclusions. There are, however, several afterthoughts.

First of all, institutional critique is strongly centralized. Only a few institutions and a dozen or so artists and curators regularly reflect upon the workings of contemporary art. This is strange, because the lack of social security and uncertain prospects for the future affect less well-known artists and institutions more strongly. It is impossible to assess the extent to which the knowledge created during episodes like those discussed earlier actually circulates. Do the peripheries know what the center is doing? Do proposals and criticisms find their audience? Can we even talk about a single field of contemporary art? Or, rather, is it a porous and unequal space?

This reflects a more general model of how contemporary art works: It reproduces inequality between a mass of unrecognized artists and a widely influential margin. The "winner takes all" principle constitutes a cruel economy of art (Szreder, 2016, pp. 85-86). At the same time, being a successful contemporary artist in Poland does not mean that one can forget about problems with employment or social security (Krajewski \& Schmidt, 2017, pp. 37-42). The small number of people practicing institutional critique provokes reflection on why questioning of the rules of art is not more common, especially considering the economic troubles that both beginner and professional artists face on a regular basis (Kozłowski et al., 2013). If we consider institutional critique to be an indicator of the autonomy of the visual arts (as I did in the first part of the article), then such centralization suggests that this autonomy is limited to privileged positions within the art field: major state-funded galleries and recognized artists. For the rest, the pressures of local politics and the necessity to survive in the art market might mark the boundaries of their creative freedom.

Secondly, new institutionalism, the idea of a critical museum and similar programs, nudged art institutions towards reflecting on their functioning and increasing their sensitivity to the environment. Their new policies, such as educational activities or involvement in public debates, indicate that institutional critique is pushing changes in the functioning of art institutions. What is more, the database shows that there are no strong antagonisms within the institutions themselves. Much more tension is generated on the border between contemporary art and its strange friends: the state and the market.

The role of the audience is changing. Audiences are not passive recipients of an artist's message, but active interlocutors. They are at the same time clients, who expect to be entertained or educated, and intruders, who intervene on behalf of their own norms and values. In fact, one could consider protests against controversial exhibitions as a form of institutional critique 
performed by the audience. Art that improves upon communication with the audience is expected to be more and more important.

I have decided to omit acts of institutional critique performed by audiences, as their coverage in the literature is irregular and focuses on the most spectacular cases, such as protests of fundamentalist Catholic groups. Participation of the audience in the institutional politics of art deserves its own study that would include various forms of contention: both critical of contemporary art and voicing support for artists and institutions. Audiences shape the visual arts in a similar way the market does: While most art institutions are funded by the state and at least in theory not dependent on ticket or artwork sales, their desire to reach a broader audience is a recurring motif.

Third, the state and the market shape contemporary art. State funds are a key source of income for the majority of institutions, and politicians decide about the fate of art institutions. The political change and suspension of funding for the Signs of Time program on which the creation of collections of contemporary art is dependent, confirms that art is a subsidiary of the state and should be studied as such. The market plays a different role. It is hardly considered to be a real entity, due to extremely low demand for contemporary art (Iwański, 2014). Regardless of whether it is an ideal or a real institution, the market conditions artists: from arts education, through the legal framework for the functioning of nongovernmental organizations, to cultural economy (Głowacki et al., 2009).

Institutional critique seems to occupy a space just between the pressures of the state and the market, a place where they counteract each other and provide artists with a degree of autonomy. The limited scope of institutional critique shows that this particular space of autonomy is narrow and reserved for a group of renowned artists.

\section{References}

Alberro, A., \& Stimson, B. (Eds.). (2009). Institutional critique: An anthology of artists' writings. Cambridge, MA: The MIT Press.

Bourdieu, P. (1996). The rules of art: Genesis and structure of the literary field (S. Emanuel, Trans.). Stanford, CA: Stanford University Press.

Bourdieu, P., \& Wacquant, L. (1992). An invitation to reflexive sociology. Chicago, IL: University of Chicago Press.

Brożyński, P. (Ed.). (2016). Krytyka instytucjonalna wobec transformacji. Bytom: CSW Kronika.

Chadwick, W. (2012). Women, art, and society. London: Thames \& Hudson. 
Głowacki, J., Hausner, J., Jakóbik, K., Markiel, K., Mituś, A., \& Żabiński, M. (2009). Finansowanie kultury i zarządzanie instytucjami kultury. Kraków: Uniwersytet Ekonomiczny w Krakowie.

Gromada, A., Budacz, D., Kawalerowicz, J., \& Walewska, A. (2015). Marne szanse na awanse? Raport $z$ badania na temat obecności kobiet na uczel-niach artystycznych $w$ Polsce. Warszawa: Fundacja Katarzyny Kozyry.

Huntington, S. (1968). Political order in changing societies. New Haven, CT: Yale University Press.

Iwański, M. (2014). Jak świadomie obsługiwać fantazmaty peryferyjnego rynku sztuki. In T. Załuski (Ed.), Skuteczność sztuki (pp. 96-113). Łódź: Muzeum Sztuki w Łodzi.

Koopmans, R., \& Rucht, D. (2002). Protest event analysis. In B. Klandermans \& S. Staggenborg, Methods of social movement research (pp. 231-259). Minneapolis, MN: UCL Press.

Kozłowski, M., Sowa, J., \& Szreder, K. (2013). Fabryka sztuki: Podział pracy oraz dystrybucja kapitałów społecznych w polu sztuk wizualnych we współczesnej Polsce. Warszawa: Wolny Uniwersytet Warszawy.

Krajewski, M., \& Schmidt, F. (2017). Wizualne niewidzialne: Sztuki wizualne w Polsce: Stan, rola i znaczenie. Warszawa: Akademia Sztuk Pięknych w Warszawie.

McCarthy, J., \& Zald, M. (1977). Resource mobilization and social movements: A partial theory. The American Journal of Sociology, 82(6), 1212-1241. https:// doi.org/10.1086/226464

Nowotny, S. (2009). Anti-canonization: The differential knowledge of institutional critique. In G. Raunig \& G. Ray (Eds.), Art and contemporary critical practice: Reinventing institutional critique (pp. 21-28). London: MayFly Books.

Raunig, G., \& Ray, G. (Eds.). (2009). Art and contemporary critical practice: Reinventing institutional critique. London: MayFly Books.

Reiter, B. (2017). Theory and methodology of exploratory social science research. International Journal of Science and Research Methodology, 5(4), 129-150.

Ronduda, Ł. (2005). Krytyka instytucjonalna w strategiach polskich artystów współczesnych na przykładzie wystawy "wybory.pl" Artura Żmijewskiego i Pawła Althamera. Obieg.pl. Retrieved July 20, 2019, from http://archiwumobieg.u-jazdowski.pl/wydarzenie/4476\#2

Sholette, G. (2011). Dark matter. Art and politics in the age of enterprise culture. London: Pluto Press.

Sikora, P. (2015). Krytyka instytucjonalna $w$ strategiach artystów i kuratorów $w$ Polsce w latach 2000-2010 na wybranych przykładach. Wrocław: BWA Wrocław.

Sikora, P. (2016, April 23). Krytyczny potencjał: Rozmowa z Patrycją Sikorą. SZUM. Retrieved July 20, 2019, from https://magazynszum.pl/ krytyczny-potencjal-rozmowa-z-patrycja-sikora/

Smithson, R. (2009). Cultural confinement. In A. Alberro \& B. Stimson (Eds.), Institutional critique: An anthology of artists' writings (pp. 140-143). Cambridge, MA: The MIT Press. 
Stimson, B. (2009). What was institutional critique? In A. Alberro \& B. Stimson (Eds.), Institutional critique: An anthology of artists' writings (pp. 20-42). Cambridge, MA: The MIT Press.

Swedberg, R. (in press). On the uses of exploratory research and exploratory studies in social sciences. In J. Gerring, C. Elman, \& J. Mahoney (Eds.), The production of knowledge: Enhancing progress in social science. Cambridge: Cambridge University Press.

Szreder, K. (2016). ABC projektariatu. Warszawa: Bęc Zmiana.

Tarrow, S. (2011). Power in the movement: Social movements and contentious politics. New York, NY: Cambridge University Press. https://doi.org/10.1017/ CBO9780511973529

Ujma, M. (2013). Krytyk sztuki na skraju: Krytyka instytucjonalna [Web log post]. Retrieved July 20, 2019, from https://magdalena-ujma.blogspot.com/2013/01/ krytyka-instytucjonalna.html

Young, J. O. (2001). Art and knowledge. London: Routledge.

Zolberg, V. A. (1990). Constructing a sociology of the arts. Cambridge, MA: Cambridge University Press. https://doi.org/10.1017/CBO9780511557712

\section{Badanie granic sztuki współczesnej: Eksploracyjne studium krytyki instytucjonalnej w Polsce 1990-2015}

Artykuł prezentuje wyniki eksploracyjnych badań nad praktykami krytyki instytucjonalnej w polskiej sztuce współczesnej. Ilościowa analiza epizodów takiego rodzaju działań artystycznych ujawnia najważniejsze problemy twórców i twórczyń oraz ich percepcję autonomii sztuk wizualnych.

Słowa kluczowe: sztuka współczesna, krytyka instytucjonalna, socjologia sztuki, sztuki wizualne.

\section{Note}

Piotr P. Płucienniczak, PhD., Assistant Professor at the Faculty of Management of Visual Culture, Academy of Fine Arts in Warsaw, Warsaw.

piotr.plucienniczak@asp.waw.pl

The preparation of the article was self-funded by the author.

No competing interests have been declared. 